\title{
IMPACT OF MACRO ENVIRONMENTAL FACTORS ON GARMENTS INDUSTRY THAT DRIVES EXPORT IN BANGLADESH
}

\author{
ISLAM Mohammad Saiful \\ Leading University, Sylhet, Bangladesh \\ PATTAK Dulal Chandra \\ Prime Bank Limited, Dhaka, Bangladesh
}

\begin{abstract}
:
It goes without saying that Garments industry of Bangladesh has drawn a special attention to the mass people in the world because of being both cost leader and quality leader at the same time. The purpose of this research paper is to analyze the garments industry in Bangladesh which is going to be an emerging tiger in the world economy. It also aims to assess the impact of macro-environmental factors affecting the industry by PESTEL analysis. Again, five forces model has been analyzed to assess the impacts of competitive external factors on the Garments industry in Bangladesh. Furthermore, Garments sector competitive responses to the primary issues affecting the industry have been evaluated here. It also outlines the primary external influences to which this industry is subject. In this case, SWOT analysis has been conducted to assess the competitive position of this industry in comparison with the global perspective. The study suggests that total export is highly correlated with the exports of garments. It also finds that there is severe lacking in the safety and security compliance, wages and compensations and code of conduct of the current organizations. Moreover, GSP facility withdrawn can impact severely on the ready made garments of Bangladesh to compete with price in the international market with China, India and Vietnam etc. The ready made garments sector of Bangladesh is enjoying cost leadership as a source of completive advantage because of cheap labor. Finally, the study would like to recommend for further improvement of garment sector in Bangladesh.
\end{abstract}

Key words: Garments sector, Export, Bangladesh

\section{Introduction}

Bangladesh is a developing country of the $3^{\text {rd }}$ world. Here, Garments sector is playing a crucial role in the economy of Bangladesh by contributing more than $10 \%$ to her total GDP. Recently, it has been emerged as the biggest source of earning foreign 
currency. EU, USA, Japan, Canada, Australia are the biggest importers of Bangladeshi Garments. It is sustaining in the market by competing with the giant companies from India and China. According to (Siddiqi, 2004), the success behind the garments industry of Bangladesh is its cheap labor compared to many countries of the world. That's why Bangladesh is able to offer it at the cheapest cost to the markets. But fire on Tazreen Fashion and Rana Plaza Collapse had a negative impact on it because lots of people were died in fire \& collapse (Telegraph, 2014). That's why government is thinking about enhancing compliances and laws that might positively impact on the overall growth of this industry. From the review of literature, it has been found that there is a research gap of analyzing the garments industry extensively that requires analyzing the industry applying different models and showing the changing nature of dependency on this sector.

The major objectives of the study are as follows:

- To assess the impact of macro- environmental and competitive internal and external factors on the Garments industry of Bangladesh.

- To evaluate the Garments sector competitive responses to the primary issues affecting it.

- To outline the primary external influences to which Garments sector is subject.

- To make a discussion of three scenarios that link direct to environmental analysis.

\section{Research Methodology}

2.1. Type of research: The research is empirical in nature. Theoretical analysis along with numerical evidences has been used to validate the findings of the research.

2.2. Data Sources: Data required for the research were collected from secondary sources such as different websites, journals, economic reviews etc. Data has been used in different models for assessment and econometric analysis. Data collected from different sources were verified and insignificant mismatching has been found.

2.3. Variables Covered: For evaluating the impact of RMG export on total export well accepted regression model has been developed in the research. The regression model has covered 2 variables including total export as dependent variable and RMG export as independent variable.

2.4. Sampling Method: For conducting correlation and regression analysis, time series data of last 16 fiscal years (FY 2001-FY 2016) have been used.

2.5 Data Analysis Tools: Secondary data entry was conducted in SPSS 20.0 data editor and analyzed under specific hypothesis. Statistical tools like correlation coefficient, regression coefficient, and coefficient of determination, analysis of variance (ANOVA) and trend analysis have been used. 


\section{Literature review}

Bangladeshi RMG sector violets the working condition of ILO standard and code of conduct frequently (Quddus and Uddin: 1993, Dasgupta, S: 2002). The RMG sector of Bangladesh is a key export sector of the economy of Bangladesh which is creating opportunities for employment and source of foreign exchange (Kamal, M. Hossin, S. and Billah, M: 2010). Absence of labour union, informal recruitment, sudden lay off, wage discrimination, long working hours and irregular payment are some poor practices in Bangladeshi garments (Ahmed, 2012). Though this sector has a great impact on Bangladeshi economy, its working condition, safety programmes and labour welfare are below ILO standard (Ahmed, F: 2012). More than 20 million people, directly or indirectly, 2.88 million women directly depend on this sector (BGMEA: 2016).

This sector contributes about $78 \%$ of total export and about $10 \%$ of GDP of Bangladeshi economy (BGMEA: 2016). It is alarming that women are the most sufferers because they have to face sexual harassment inside as well as outside of the factories (Gonzales. 2012). Though the RMG sectors of Bangladesh are doing tremendous in the global market, Bangladesh has faced some challenges like competition with China, India and Vietnam at present time (Haider, 2012). With the help of the government of Bangladesh, BGMEA the apex trade body of Bangladesh is trying to overcome the present challenges.

Over the last two decades, there were over $20 \%$ growth rate in the RMG industry. In the fiscal year 2011-2012 the BGMEA exported19089.69 million USD whether the country's total export were 24287.66 million USD (BBS, 2014). In February of the current fiscal year (2012-2016) BGMEA exported 13830.50 million USD with a growth of $10.13 \%$ ( BGMEA: 2016).

According to Bhuiyan, (2013), the women employees are the source of cheap labor and they are playing a key role in the overall development of the Bangladesh Readymade Garments. On the other hand, Kibria et al. (2016) concluded that most important reason of success of Bangladesh Garments in the international market is GSP and if Bangladesh cannot enjoy the GSP, it will impact immediately in the total export of Bangladesh. But Ahmed \& Hossain, (2009) suggested that if Bangladesh cannot ensure the safety of the employees at working place, it will impact severely at one point of time because the international buyers like to purchase of products from the company complying the safety of employees.

\section{Garments industry in Bangladesh}

Garments sector is one of the promising sectors in Bangladesh. Bangladesh ranks the second in the whole world in manufacturing Ready Made Garments after China. It started its journey in late 1970s. The success in this sector has not come overnight. It has passed a long way to touch the acme of success. It goes without saying that the impact of Multi Fibre Arrangement (MFA) quotas and the Hrkin Bill in 
1985 and 1994 respectively on Garments industry in Bangladesh. The key success factors behind the garments industry were MFA bilateral quota system imposed by developed apparel countries, supportive trade policy of the government and the low wages in Bangladesh.

The MFA quota was phased out in 2004. And there was a concern that this can shut down the industry but it grew more after 2004 in Bangladesh. With only 9 units, it entered in the export market in 1978 and earned only $\$ 0.069$ million. Currently, the number of RMG units is more than 5000 in Bangladesh and it has earned 17 billion US dollar in the last fiscal year. It is maintaining an average of $15 \%$ growth in spite of having a lot of problems. More than 4 million people work here right now. $90 \%$ of the total labor in this sector is female. At present, $80 \%$ of the export earning comes from this sector and more importantly, it is contributing $10 \%$ to our total GDP.

\section{Analysis and Findings}

From SWOT analysis, PESTEL analysis, Five Forces Model analysis, Porters Generic Model analysis and econometric analysis on Garments industry of Bangladesh, findings of the study are categorically discussed in the following subsections:

Table 1: SWOT Analysis on Garments Industry in Bangladesh

\begin{tabular}{|c|c|c|}
\hline & Strength & Weakness \\
\hline $\begin{array}{l}\text { Internal } \\
\text { Factor }\end{array}$ & $\begin{array}{l}78 \% \text { export oriented } \\
\text { Lowest labor cost } \\
10 \% \text { contribution to GDP } \\
4 \text { million direct cheap worker } \\
\text { Women empowerment and their } \\
\text { productive role in society } \\
\text { Poverty alleviation } \\
\text { Low price energy } \\
\text { Favorable port facilities } \\
\text { One stop services } \\
\text { GSP advantages } \\
\text { FDI is appreciated } \\
\text { Bank interest is low } \\
30 \text { years of experience in the } \\
\text { production and distribution } \\
\text { Maintains international quality }\end{array}$ & $\begin{array}{l}\text { Lacking in market tactics } \\
\text { Dependency on raw foreign materials } \\
\text { Unskilled workers } \\
\text { Improper working environment } \\
\text { Gender division of labour } \\
\text { Lack of managerial knowledge } \\
\text { Low unit labour cost } \\
\text { Long working hours } \\
\text { Poor accommodation facilities } \\
\text { Insufficient of loan } \\
\text { Safety problems } \\
\text { Deficiency in creativity } \\
\text { Lack of proper training organization } \\
\text { Culture of speed money } \\
\text { Communication gap } \\
\text { Small number of manufacturing method }\end{array}$ \\
\hline & Opportunities & Threat \\
\hline $\begin{array}{l}\text { External } \\
\text { Factors }\end{array}$ & $\begin{array}{l}\text { An alternative market industry in the } \\
\text { world against China } \\
\text { As a country of LDC, Bangladesh is } \\
\text { committed to enhance export trade } \\
\text { Promotion for skill manpower } \\
\text { Skilled technologies should be } \\
\text { introduced } \\
\text { New market(EU, Africa, Latin } \\
\text { America) } \\
\text { Utilization of huge unused human } \\
\text { resources }\end{array}$ & $\begin{array}{l}\text { Political unrest, instability, hartal, strike etc } \\
\text { Global economic recession } \\
\text { Alternative market of Myanmar, Vietnam, } \\
\text { Laos, Latin America and Caribbean states } \\
\text { Highly competitive market } \\
\text { Import of backward machines and tools }\end{array}$ \\
\hline
\end{tabular}




\section{PESTEL Analysis on Garments Industry in Bangladesh:}

Political Analysis: A country's development largely depends on the country's smooth and stable political system. Democratic government, fiscal policy, monetary policy helps to gain economic growth. Bangladesh is appearing as a new emerging tiger by the help of its readymade garments and textile sector. But in recent times a black shadow is appearing in the sky of Bangladesh because of political unrest, strike, conflicts, labour unrest etc (Hossan et al. 2012).

The most noticeable and important features of political system are as follows

* Absence of proper democratic system

* Absence of rule of law

* Corruption and terrorism

* Absence of democratic practice among political parties

* Pressure from the Islamist

* Confrontational situation among political parties

Though the problems, stated above, exist in Bangladesh, the government has taken many positive steps and initiative in favor of garments sector. Foreign investments are welcomed. Favorable policy, tax holiday, export-import policies, investments incentives, reduced import duties on capital machinery and spares are some important initiative helping the garments sector.

Economic Analysis: Garments sector is currently contributing about $10 \%$ to GDP $^{1}$ and it is the highest single contributor of Bangladesh economy (BGMEA: 2016). About 20 million people are directly or indirectly involved in this sector. And about $78 \%$ of the employees are women who are playing a pivotal role in decision making, poverty alleviation in their family (BGMEA: 2016). A platform for 2.8 million women to engage in new productive role has been created by this industry. Besides, this industry is accelerating the industrial growth and employment opportunities for the unemployed people in Bangladesh. Banks are making a lot of profit only from this sector by export and import services.

\section{Social Analysis:}

Bangladesh is a country of about 160 million people and a large number of her people are unemployed. Women are the most unused labor force in our economy and those who are working are not getting well compensation packages as compared to men (Bhuiyan, 2012). And it is garments that have helped them to engage in the mainstream of the economy. About $78 \%$ of total garments worker are woman who are significantly contributing to their families living in slums and villages. Hence, they are participating in decision making of families. From this point of view, the social impacts of garments are as follows.

$\checkmark \quad$ Woman empowerment has been achieved in private and public sector.

$\checkmark \quad$ They are contributing to increase savings.

$\checkmark \quad$ They are interested population control. 
$\checkmark \quad$ Economic solvency of woman has been achieved.

$\checkmark$ Their Children are getting educated more.

$\checkmark$ Awareness about Health care has been increased

$\checkmark$ Standard of living is increasing day by day.

\section{Technological Analysis:}

Bangladesh is not technologically so developed as compared to other big giants in the international markets. It is still using obsolete technologies because they have to pay a high amount of money to acquire ultra modern technology. Although, government has given duty free import of technology and machinery for garments, it is increasing the fixed and operational cost. If they could purchase it from the local market, it would be a blessing for the garments industry of Bangladesh. China, Vietnam, Taiwan etc are more advanced in technological advantage.

\section{Ecological:}

Ecological impacts of garments on the environment are not well enough to describe because of poor waste management. The improper drainage system is mainly responsible for it. Besides, government is not taking enough steps for waste management in Dhaka city. Sound and air pollution are the outcome of this industry.

\section{Legal:}

Government always encourages garments industry by its supportive hands most of the time. That's why a large number of companies have been established here and there in the city. But recent fire in some notable garments company has drawn the sight of the government. It has increased some legal and compliance issues. The workers do not get proper wages and remuneration, working environment and safety from the companies (Muhammad, 2011). That's why government has intervened on this issue by enforcing the law and order system.

\section{The five competitive forces analysis on Garments of Bangladesh:}

Bargaining power of suppliers: Producers of inputs like raw materials, semifinished goods, labor, components etc are suppliers. And firms are the buyer of these raw materials and semi-finished goods. Mutual understanding between the supplier and the buyer helps to grow an industry. But when one party becomes strong, it tries to bargain for gaining. The suppliers of Garments in Bangladesh are powerful in case of raw materials because most of them are imported. But still Bangladesh is collecting the raw materials at world price form the abroad. She has a good reputation to the suppliers for timely payment. Besides, B2B LC ${ }^{1}$ is permitted in Bangladesh, which is giving extra facilities to the industry. Again, it is a good side that raw materials are coming from domestic markets also at present. And the powers of local suppliers are increasing day by day. But in case of labor supply, industry is in advantageous position. The suppliers of labor are not so strong as compared to the suppliers of raw materials because labors are adequate in this country. 


\section{Bargaining power of customers:}

The buyers of Bangladeshi garments have more bargaining power than themselves. Bangladesh is the second largest manufacturer of garments in the world. Hence, she serves a lot of markets in world. The products of Bangladeshi Garments are very popular all over the world because of two reasons. It maintains both quality and price at a time. Because, input cost as labor is very low in Bangladesh. Buyers can switch to the products of China and India easily if Bangladesh fails to provide quality and cheap products at a time. Bangladesh is also the best for outsourcing in garments. That's why many international brands are coming to Bangladesh to get their work done by Bangladesh. That's why there are many franchises and subsidiaries in this country. Finally, quota system, GSP and low labor cost are making some balances in the market for Bangladeshi garments in the world.

\section{Threat of new entrants/Barriers to entry:}

Yes, there is threat of new entrants for the existing companies. In Bangladesh, it is still a growing industry due to high demand in the whole world. About $80 \%$ of total export income comes from the garments sector in Bangladesh. That's why government of Bangladesh has lightened the restrictive requirements in entering into the market. It is observed that Bangladesh entered into the international markets by only nine units. And now, there are more than 5000 units in Bangladesh that are continuously producing products. The reasons behind the dramatic growth of units are the friendly government policy, availability of cheap labor, domestic and international demand (Clark \& Kanter, 2011). Bangladesh Government always encourages this industry by its supportive hands in order to increase export income. For local market, the threat is not so high because there are a lot of unutilized resources in Bangladesh. She could not reach to the economics of scale and thus allows new entrants in the market. So, in that case threat to new entry is negligible sine there is a high growth. But if we consider internationally, there is high threat of new entrants because it is a labor intensive industry. And many countries of the world like China and India are trying to capture the international market by their huge labor and technological advantage.

\section{Threat of substitutes:}

There is threat of substitute for Bangladeshi Garments because China and India are capturing market faster than Bangladesh. She is lagging behind to some extent because of poor country barding and less power to influence customer. So, sometimes customers prefer other's products to Bangladesh. Besides, government has less reputation in the world than that of China and India. Moreover, many international brands don't want to come due to unstable political situation, power crisis and red tape. So, to ensure growth and profitability, Bangladesh should try to substitute the Indian and Chinese products by providing cheap and quality products.

\section{Competitive rivalry between existing players:}

Bangladesh is competing with many big players in the international markets. She ranks $6^{\text {th }}$ in case of supplying garment products in US and EU market. China and India are big players in the market. Bangladesh imports raw materials and uses other factors of production like cheap labor to make it final goods at cheaper rate (Mottaleb \& 
Sonobe, 2011). If she could use local materials, she would be the market leader and cost leader at a time in this industry in the whole world. That's why competition between existing players is more or less high because there are many players about same size in the industry. They have similar strategies in capturing the market. Besides, there is not much differentiation between players and their products due to the nature of products. But, there is not sever problem for this because due to high demand, the industry is maintaining an average of $15 \%$ growth annually. And there are no notable barriers to exit from the market. Many foreign investors are coming to Bangladesh for investing on garments. So, there are always some balances.

Analysis of Porters Generic Model Matrix and Garments industry of Bangladesh

\begin{tabular}{|c|c|}
\hline Cost leadership & $\begin{array}{c}\text { Differentiation } \\
\text { strategy }\end{array}$ \\
\hline $\begin{array}{c}\text { Focus strategy } \\
\text { (Low cost) }\end{array}$ & $\begin{array}{c}\text { Focus strategy } \\
\text { (Differentiation) }\end{array}$ \\
\hline
\end{tabular}

Figure 1: Porters Generic Model Matrix Analysis on Garments industry in Bangladesh

Generic Model of Porters suggests that it is important for any organization or industry to follow one of the above strategies to achieve competitive advantage from the market (Porter, 2004). Here, Bangladeshi garments follow the cost leadership strategy. That's why, this industry performed well even in the global economic recession. But, becoming cost leadership and keeping it for the long run is very difficult due to continuous price rise of raw material and power. But, still Bangladesh is able to do it for cheap labor.

\section{Econometric Analysis:}

Impact Garments Export on Total Export in Bangladesh:

From the econometric analysis of the data of last sixteen fiscal years (20012016) regarding Garments export and total export in Bangladesh, following statistical outcome has been found: 
Table 2: Statistical Output

\begin{tabular}{|l|l|l|l|l|l|l|}
\hline & \multicolumn{5}{|l|}{ Total Export } \\
\hline & $\begin{array}{l}\text { Correlation } \\
(\mathbf{R})\end{array}$ & $\begin{array}{l}\mathbf{R} \\
\text { Square }\end{array}$ & $\begin{array}{l}\text { Constant } \\
(\boldsymbol{\alpha})\end{array}$ & $\begin{array}{l}\text { Beta } \\
(\boldsymbol{\beta})\end{array}$ & $\begin{array}{l}\mathbf{p} \\
\text { Value }\end{array}$ & $\begin{array}{l}\text { Null } \\
\text { Hypothesis }\end{array}$ \\
\hline RMG Export & .990 & .981 & -364 & .990 & 0.00 & Rejected \\
\hline
\end{tabular}

\section{Coefficient of Correlation:}

From the table-2, it has been found that there is a high degree of positive correlation $(R=0.990)$ between $R M G$ export and total export.

\section{Regression analysis:}

The simple linear regression is developed by taking RMG export as the independent variable and total export as the dependent variable.

The standardized regression model is: $E X P=\alpha_{0}+\beta_{0} R M G E X P+\epsilon_{i}$ (residual factors)

The fitted regression model is: $E X P=-364+0.990$ RMGEXP

Here, $\beta_{0}=0.990$ implies that if RMG export increases by Tk. 1 then total export will be increased by Tk. 0.990 . Finally, if RMG export is zero then total export will also be zero.

\section{Coefficient of Determination:}

Again, the value of $R^{2}=0.981$ or $98.1 \%$ or $98 \%$ this implies that $98 \%$ of the total variation of total export can be explained by the variation of RMG export and the remaining $2 \%$ variation can be explained by the variables which are not included in the regression model.

\section{Test of Hypothesis:}

In this study, we have developed the following hypothesis:

$H_{0}$ : The RMG export and total export are not significantly related.

$H_{1}$ : The RMG export and total export are significantly related.

Here, the value of $p$ (significance) is 0.000 which is less than 0.05 (significance level). Hence, the null hypothesis is rejected which means that RMG export and total export are significantly related. 


\section{Trend Analysis:}

Graphical presentation of total export and RMG export corresponding to several years are given below.

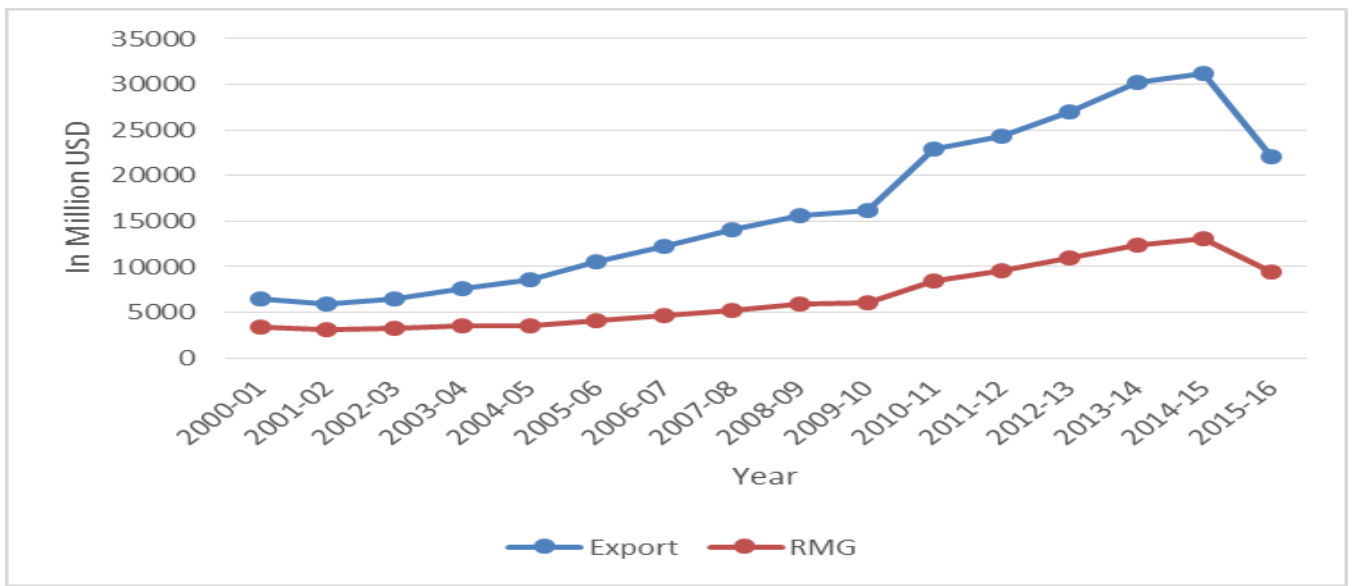

Figure 2: Comparative trend analysis of total export and RMG export

Source: Bangladesh Economic Review 2015-16; Data of fiscal year 2015-16 is till February 2016

From the above figure, we have found that there are increasing trend of both the total export and RMG export in different phases throughout last sixteen fiscal years (observation period). At the beginning of the observation period total export and RMG export were low and close to each other which indicates more dependency of total export on RMG export. Gradually the gap between total export and RMG export is increasing which indicates that decreasing trend of dependency on RMG export only and evidence of export earnings from other sectors as well. The above figure shows that there is a massive growth in total export and RMG export throughout the last decade.

\section{Conclusions and Recommendations}

From the above analysis, it can be said that Garments is a blessing for Bangladesh no doubt. It is growing day by day having a lot of political instability. Though, there was little impact of global economic recession on Bangladeshi RMG sector, the external factors like political instability, labor unrest and inadequate safety system are responsible for decreasing the image of Bangladeshi Garments to the global arena. If this situation continues, this might be a red signal for the growth of this sector. From the analysis of several models and econometric analysis following recommendations can be drawn:

- RMG sector of Bangladesh should be given paramount priority by any government for its continuous development because the total export is highly correlated with the RMG exports. 
- BGMEA and other government licensing authority should ensure the preconditions of a garments company in terms of code of conduct, fire and safety, working environment and so on before approving any new garments in Bangladesh.

- Equal opportunities in terms of compensation packages for both man and woman should be ensured by both companies and monitoring authority.

- Garments industry of Bangladesh should be kept free from Hartal, strike and other political instability by all political parties because this sector is the biggest bread earners for Bangladesh.

- Consular office and government body need to be more diplomatic regarding the bargaining of continuous GSP facility because Bangladesh as a small and under developed country cannot compete with other developed country like China, India, and Vietnam and so on.

- The monitoring and licensing authority of Bangladesh Garments industry should ensure the internationally accepted policies regarding safety and security, compensation, working environment and environmental protection because recent accident in Rana Plaza and Tazreen fashion has reduced the goodwill of Bangladeshi Garments.

- The scope of foreign investment should be increased by the government through providing more facilities in the EPZ so that this sector becomes more negotiating in the international markets.

- More international markets should be haunted so that exports increases and more people can engage themselves in this business.

- Central Separate training center of employees, subjects in the University and Research and Development center should be established so that this sector gets continuous development.

- Lest but not the last, more banking and government facilities in terms of tax rebate, low interest rate, zero LC margin should be enhanced to boost up this sector so that they can sustain in the international market in case of pricing when there will be no GSP facility.

\section{Reference}

Ahmed, M. I and Hossain, M. S(2006) "Future prospects of Bangladesh's Ready-made Garments Industry and The Supportive Policy Regime", Policy Note Series: PN 0702. Policy Analysis Unit (PAU). Research Department, Bangladesh Bank, Dhaka, Bangladesh.

Ahmed, J., and Hossain, T., (2009) Industrial Safety in the readymade garment sector: A developing country perspective, Sri Lankan Journal of Management, Vol. 14, No. 1, pp.( 2-12)

Ahmed, F: (2012) Improving social compliance in Bangladesh Ready-made Garments Industry, La Trobe University, Australia 
BBS. (2014) Statistical Year Book of Bangladesh; Bangladesh Bureau of Statistics, Ministry of Planning, Government of The People's Republic of Bangladesh.

Bhuiyan, M.Z.A. (2012) Present Status of Garment of Workers in Bangladesh: An analysis, IOSR, Journals of Business and Management, Vol. 3, No. 5, pp. 21-43

Bhuiyan, M. I., (2013) Reasonable Wages for workers to eliminate unrest of Bangladesh's RMG sectors, Bangladesh Development Research Working Paper Series Report no. 17, Dhaka

Bhattacharya, D., M. Rahman and A. Raihan, (2002) Contribution of the RMG sector to the Bangladesh Economy, CPD Occasional Series, Paper No. 50.

BGMEA (2016) [Online] Available from: http://www.bgmea.com.bd[Accessed April 2016]

Clark, C. \& Kanter, S. (2011) Violence in the RMG Industry in Bangladesh, International Connections: Labor Standards Issue, Center for International and Competitive Studies (CICS), University if Michigan, Vol. 3, No. 1, pp. 2-11

Dasgupta, S. (2002) Attitude towards trade unions in Bangladesh, Brazil, Hungary and Tanzania. Journal Article on International Labor Review, Volume 14(1)

Gonzales, M.H. (2012) The Readymade Garments industry in Bangladesh: A Means to reducing Gender based social exclusion of Women? Journal of International Women's Studies, 11 (1); pp. (142-178)

Haider, M. Z. 2012. "Competitiveness of Bangladesh Ready-made Garment in Major International Markets". Asia-Pacific Trade and Investment Review.Vol. 3, No. 1, June

Hossan, C.G., Rahman, Sarker., MAR \& Afroze, R. (2012) Recent unrest in the RMG sector in Bangladesh: Is this an outcome of poor labor practices? International Journal of Business Management, Vo. 7 No. 3, pp. 201-217

Kamal, M. Hossin, S. and Billah, M (2010) Labor unrest and Bangladesh Labor Act-2006, A study on Ready Made Garments Factories in Gazipur, Journal of Business and Technology, Dhaka

Kibria, A.M..B.G., Martin, S., Sharmin, R., (2016) Impact of GSP Cut: The case of RMG sector in Bangladesh, Journal of Social Sciences, Vol. 6, No. 1, pp. (1-11)

Mottaleb, A.K. and T. Sonobe. (2011) An inquiry into the rapid growth of the Garment Industry in Bangladesh". GRIPS Discussion Paper

Muhammad, A. (2011) Wealth and Deprivation: Readymade Garment industry in Bangladesh, Economic and Political weekly, Vol. XLVI (34), pp. 19-26

Porter, M.E. (2004) Competitive Strategy, Boston: Free press

Quddus, M. and Rashid, S. (2000) Entrepreneur and Economic Development: The remarkable story of Garments exports from Bangladesh, Journal of Bangladesh Studies, 2000, Vol, 2(1), The University Press Limited, Dhaka, Bangladesh

Rahman, M. Bhattachayia, D. and Moazzem, K. G. (2007), "CPD Study in Bangladesh's Apparel Sector on Post-MFA Period: A Benchmarking Study on the Ongoing Restructuring Process", Centre For Policy Dialogue (CPD) Bangladesh.

Siddiqi, Hafiz G. A. (2004) The Readymade Garment Industry of Bangladesh, Dhaka, The University Press Limited.

Telegraph (2014) [Online] Available from:http://www.telegraph.co.uk/news/worldnews/asia/bangladesh/9701826/Banglades h-factory-fire-kills-111-garment-workers.html [Accessed April 08, 2016] 